\title{
NON-LINEAR DYNAMIC SOIL-STRUCTURE INTERACTION ANALYSIS OF BUILDINGS
}

\author{
Abdelhacine Gouasmia ${ }^{1}$, Kamel Djeghaba \\ Dept of Civil Engineering, University of Badji Mokhtar, BP 12 El Hadjar, 23220 Annaba, Algeria, \\ E-mail: 'gouasmia_abdelhacine@yahoo.fr
}

Received 12 March 2007; accepted 17 Dec 2007

\begin{abstract}
The objective of this research is to evaluate the effects of soil-structure interaction (SSI) on the modal characteristics and on the dynamic response of structures. The stress had an impact on the overall behaviour of five storeys reinforced concrete $(\mathrm{R} / \mathrm{C})$ buildings typically encountered in Algeria. Sensitivity studies are undertaken in order to study the effects of frequency content of the input motion, frequency of the soil structure system, rigidity and depth of the soil layer on the dynamic response of such structures. This investigation indicated that the rigidity of the soil layer is the predominant factor in soil-structures interaction and its increases would definitely reduce the deformation of the R/C structures. On the other hand, increasing the period of the underlying soil will cause an increase in the lateral displacements at storey levels and create irregularity in the distribution of storey shears. Possible resonance between the frequency content of the input motion and soil could also play an important role in increasing the structural response.
\end{abstract}

Keywords: foundation, $\mathrm{R} / \mathrm{C}$ frame, soil-structure interaction, rigidity, direct method, finite element method.

\section{Introduction}

The Algerian earthquake of magnitude Mw6.8 which struck Boumerdes-Algiers on May 21, 2003, is considered among the largest earthquakes to have occurred in the region since the El-Asnam earthquake (Ms7.3 in 1980) [1]. It caused important damages in the Boumerdes region, where many buildings collapsed totally and many of them have been seriously damaged.

A large investigation have been undertaken in order to understand what have caused such defects in modern design buildings. Amongst many causes, soil conditions in the Boumerdes region are suspected to have played a role in the amplification of earthquake input motions.

In this respect, taking advantage of the new and emerging concept of seismic structural design, the so-called performance-based Design (PBE), a careful consideration of all aspects involved in structural analysis is performed. One of the most important aspects of structural analysis is soil structure interaction (SSI). Such interaction may alter the dynamic characteristics of structures and consequently may be beneficial or detrimental to the behaviour of structures. Not taking into account these structural response amplifications may lead to an under-designed structure resulting in a premature collapse during an earthquake.

Analytical methods of SSI concentrates mainly on a single degree of freedom systems and analysis/design of long and important structures such as large bridges and nuclear power plants, and rarely on regular type buildings.

Thus the main idea behind this investigation is motivated by the fact that there is a still great uncertainty as to the significance of SSI for ordinary structures typically encountered in Algeria. There may be both beneficial and adverse effects of SSI. However, in many cases SSI is simply ignored in a design without establishing, whether it will increase or decrease the response of the structure. A second objective is that the probability of an earthquake of magnitude 7 or larger may occur in regions that have experienced strong earthquakes such as El-Asnam or Boumerdes. Therefore studies which include SSI effects will help better predict the performance of structures during future earthquakes.

The first studies of SSI showed that there are mainly two types of SSI effects, ie inertial and kinematic interactions. Inertial interaction effects are generally accompanied by an increase of the fundamental period of the system, 
while kinematic interaction effects do affect the foundation input motions [2, 3].

Past practical procedures used for design purposes generally neglect kinematic interaction, while inertial interactions are taken into account. Structural models in which SSI effects had been studied have not changed over the last 30 years, where an elastic equivalent simple damped oscillator having a rigid foundation resting on or partially embedded into a homogeneous or stratified half-space has been adopted. Therefore solutions are available for rigid circular, rectangular and strip foundations on various soil profiles [4].

Currently, efforts are made by some researchers to allow full SSI analyses (kinematic and inertial interactions) to be performed on structures of general shape [5].

It is appropriate to note that the main assumption behind all the methods that have been briefly reviewed thus far is elastic behaviour of superstructure, a major limitation for structures that are expected to behave inelastically under severe earthquake motions. Under such conditions, the soil non-linearity is also expected to contribute or influence the overall deformation of the soil structure system. At present, this can only be dealt approximately.

SSI studies that take into account the yielding of structures and soil non-linearity are scarce, if at all. This study investigates the effects of the non-linearity of the soil-structure system on the overall behaviour in terms of displacements and stresses.

In the solution of SSI problems, it is required to carefully model the unbounded nature of the underlying media. Many numerical methods have been developed to solve this problem, such as using transmitting or absorbing boundaries at the truncated region of the soil.

There are two main approaches for analysing soil-structure interaction, namely the direct method and the substructure method [6]. Both methods are still being developed to overcome the shortcomings related to each of them, especially the non-linearity and unboundedness nature of the problem. Recent developments in the finite element method made by Wolf [7], have shown that using the direct method with a limited zone of the soil may capture the essential aspects of the non-linear nature of the problem related to soft soil conditions.

In general, SSI will influence the soil-structure system in three ways:

1) It will alter the dynamic characteristics of the soilstructure system, such as modal frequencies and vibrating mode shapes. In particular, the fundamental period will elongate and the rigid body motion of the structure will be changed. 2) It will increase the modal damping as part of the soil will contribute to the overall damping of the soilstructure system (the so-called radiation damping). 3) It will modify the free-field ground motion [8].
In a seismic soil-structure interaction analysis, it is necessary to consider the infinite extent and layered nature of soil strata, and the non-linear behaviour of soft soils. The objective of this study is to perform a rigorous seismic non-linear soil-structure interaction analysis in the time domain to satisfy the above requirements while the results are compared with those of fixed base conditions.

Analytical models were developed by finite element method (FEM) for numerical analysis. Different analyses were performed on a real 5 -storey reinforced concrete building in terms of comparative results. The dynamic behaviour of structural systems is observed and the comparative results are presented in this paper in order to clarify the importance of non-linear calculation of soil-structure systems.

\section{Finite element analysis}

In the present study we assume plane strain conditions, that is, all frames parallel to the plane of calculation (Fig 1) deform identically. This represents regularly spaced frames in the transverse direction, which are assumed to lie at each metre distance.

\section{1. Soil elements}

A 15-node triangular element is chosen for a 2D analysis (Fig 2). This element is powerful and provides an accurate calculations of stresses and strains. The stresses are evaluated at the 12 stress points contained in the element as indicated (Fig 2).

Mohr-Coulomb model is used as a first approximation of soil behaviour in general. The model involves

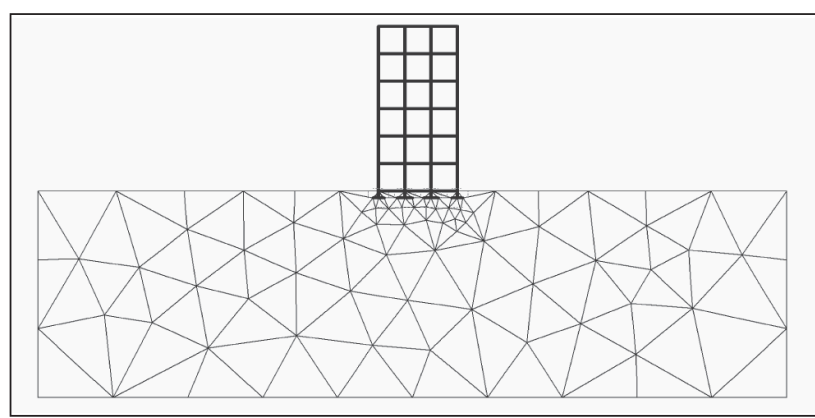

Fig 1. Finite element discretisation of the soil-structure system

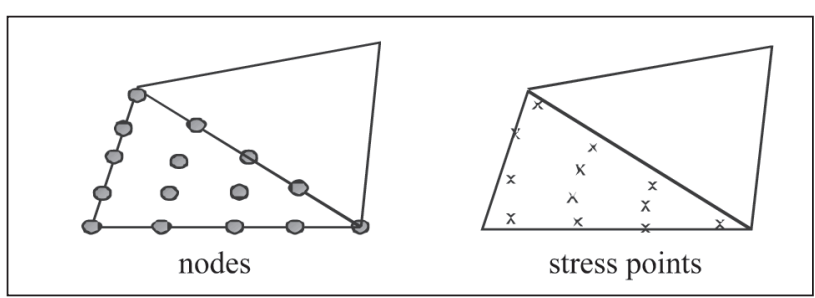

Fig 2. Position of nodes and stress points in soil elements, Brinkgreve et al [9] 
5 parameters, namely Young's modulus, E, Poisson's ratio, $\checkmark$, the cohesion, $c$, the friction angle, $\phi$, and the dilatancy angle, $\psi$.

\subsection{Interfaces}

Interfaces are used to model the interaction between structures and the soil. A typical application of interfaces would be to model the interaction between a foundation and the soil. The interaction is modelled by choosing a suitable value for the strength reduction factor in the interface. This factor relates the interface strength (foundation friction and adhesion) to the soil strength (friction angle and cohesion).

\subsection{Interface elements}

Interfaces are composed of interface elements. Fig 3 shows how interface elements are connected to soil elements. When using 15-node soil elements, the corresponding interface elements are defined by 5 pairs of nodes. In the same figure, the interface elements are shown to have a finite thickness, but in the finite element formulation the coordinates of each node pair are identical, which means that the interface element has a zero thickness.

\subsection{Interface strength}

The Coulomb criterion is used to model the elasticplastic behaviour of interfaces, where small and large displacements are taken into account; thus allowing proper modelling of soil-structure interaction problems.

For small displacements (elastic) the interface shear stress $\tau$ is given by:

$$
|\tau|<\sigma_{n} \tan \phi_{i}+c_{i}
$$

For plastic behaviour $\tau$ is given by:

$$
|\tau|=\sigma_{n} \tan \phi_{i}+c_{i},
$$

where $\phi_{i}$ and $c_{i}$ are the friction angle and cohesion of the interface; $\sigma_{n}$ and $\tau$ are the normal stress and shear stress at the interface element. The strength properties of interfaces are linked to the strength properties of the soil layer. The interface associated strength reduction factor $\left(R_{\text {inter }}\right)$ is calculated from the soil properties by applying the following:

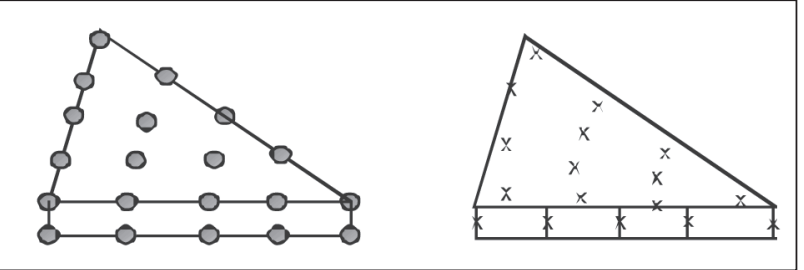

Fig 3. Distribution of nodes and stress points in interface elements and connection with soil elements, Brinkgreve et al [9]

$$
\begin{gathered}
c_{i}=R_{\text {inter }} c_{i}, \\
\tan \phi_{i}=R_{\text {inter }} \tan \phi_{\text {soil }} \leq \tan \phi_{\text {soil }}, \\
\int_{\mathrm{i}}=0^{\circ} \text { for } R_{\text {inter }}<1, \\
\text { otherwise } \int_{\mathrm{i}}=\int_{\text {soil }} .
\end{gathered}
$$

\subsection{Boundary conditions}

The unbounded nature of the soil medium requires special boundary conditions (BC) that do not reflect seismic waves into the soil-structure system.

Various models of BC exist that enable the energy transmission, (Lysmer and Kuhlemeyer [10]), the most commonly used in the FEM are of the viscous type.

The position of the local viscous boundaries should be far away from the structure in order to obtain realistic results. In recent studies it is recommended that the location of the transmitting boundary to be selected far away 810 times of the foundation base width [11].

The BC used in this study are based on the method described by Lysmer and Kuhlmeyer [11].

The normal and shear stresses absorbed by a viscous damper are:

$$
\begin{gathered}
\sigma_{n}=-c_{1} \rho V_{p} \dot{u}_{x}, \\
\tau=-c_{2} \rho V_{s} \dot{u}_{y},
\end{gathered}
$$

where $\rho$ is the density of the materials, $V_{p}$ and $V_{s}-$ the $\mathrm{P}$ wave velocity and the $\mathrm{S}$ wave velocity, respectively; $c_{1}$ and $c_{2}$ are special relaxation coefficients that are introduced to improve the absorption effect of the viscous damper. For practical applications, reasonable values are: $c_{1}=1$ and $c_{2}=0,2$. However, these values do not assure fully absorbed $\mathrm{S}$ waves, and additional research is needed at this point.

\section{Characteristics of soil-structure model}

In order to investigate the soil-structure-interaction of regular type reinforced concrete buildings with isolated footings response due to earthquake ground motion, 48 models of the 5-storey building have been examined. Table 1 shows the dynamic properties and the geometry of the 5-storey R/C building model.

Since the dynamic response of this soil-structure system depends on the frequency content of the input motion and its variation through the soil layers, the interaction between foundation and it's underneath soil layers has been studied. Three different types of soil layers with different depths of 30, 50 and $100 \mathrm{~m}$ have been considered. In each analytical model different shear wave velocities ranging from 50 to $1200 \mathrm{~m} / \mathrm{s}$ simulating soft to hard soil conditions have been used.

The dynamic characteristics of 3 types of soil layers 
Table 1. Dynamic characteristics and geometry of 5-storey model

\begin{tabular}{|c|c|c|c|c|}
\hline Structural properties & $\begin{array}{c}\text { Shear wave velocity } \\
\qquad S, \mathrm{~m} / \mathrm{s}\end{array}$ & \multicolumn{3}{|c|}{ Depth of soil layer $H, \mathrm{~m}$} \\
\hline \multirow{6}{*}{$\begin{array}{l}\text { Superstructure: exterior footing }=1,5 \times 1,5(\mathrm{~m}) ; \\
\text { thickness }=0,36 \mathrm{~m} \text {; interior footing }=2,1 \times 2,1(\mathrm{~m}) ; \\
\text { thickness }=0,51 \mathrm{~m} \text {; area of cross-section of members }= \\
0,3 \times 0,3 \mathrm{~m}^{2} ; \text { storey height }=4,08 \mathrm{~m} \text { with a bay of } \\
4,20 \mathrm{~m} . \\
\text { Poisson's ratio }=0,20 ; \text { mass of each storey }= \\
40,21 \mathrm{KN} / \mathrm{m} \text {; mass of roof }=26,38 \mathrm{KN} / \mathrm{m}, \\
\text { critical damping ratio }=10 \%, \\
\text { modulus of elasticity }=24821129 \mathrm{KN} / \mathrm{m}^{2}, \\
\text { mass density }=2,40 \mathrm{KN} / \mathrm{m}^{3} . \\
\text { Soil: Poisson's ratio of soil }=0,20 ; \text { mass density }= \\
1,70 \mathrm{KN} / \mathrm{m}^{3} ; \text { critical damping ratio }=10 \%\end{array}$} & \multirow{2}{*}{$\mathrm{V}_{\mathrm{S}}$} & 30 & 50 & 100 \\
\hline & & \multicolumn{3}{|c|}{ Fundamental period of vibration $T_{1}(\mathrm{sec})$} \\
\hline & 50 & 2,54055 & 2,74284 & 2,73103 \\
\hline & 400 & 0,81089 & 0,84031 & 0,88972 \\
\hline & 1200 & 0,80314 & 0,81222 & 0,81214 \\
\hline & $\begin{array}{l}\text { Fixed base condition } \\
\text { (ie without SSI) }\end{array}$ & \multicolumn{3}{|c|}{0,79038} \\
\hline
\end{tabular}

will be considered, simulating soft, medium and hard soil conditions (Table 1). To study the dynamic response of soilstructure interaction, the 5-storey building model is submitted to El Centro earthquake ground motion.

\section{Discussions of results and conclusions}

For the real 5-storey R/C structure mentioned above a comparison of the results is undertaken in order to evaluate the effects of SSI, initially, in terms of fundamental periods (Table 1). One limits our presentation and analyses of results for 3 types of ground only $(=50,400,1200 \mathrm{~m} / \mathrm{s}) \mathrm{rep}$ resenting soft, medium and hard soil conditions respectively.

As expected, soft soil condition amplifies structural response and elongates natural periods, as opposed to hard soil, where for increasing values of shear wave velocities, we approach the fixed base condition (fixed base condition represents a theoretical case of a surface soil having an infinite rigidity). The severity of damages will be amplified, when the frequency content of the earthquake input motion will be near the fundamental mode of vibration of the soilstructure system.

When the depth of the soil layer increases and its stiffness decreases, the period of the soil-structure system will increase and in these cases the adjacent soil stiffness plays a very important role in decreasing or increasing the base shear for the type of structure considered.

One of the aims of this study is the necessity to explicitly consider the occurrence of one or more non-linearities (geometric and material); ie allowing for the structure to slide and uplift at the foundation interface.

It is interesting to compare the behaviour of the building that is not allowed to uplift nor slide with the behaviour of the same building that is allowed to uplift and slide (Table 2). By allowing the uplift and the slide of the foundations the lateral displacement at the top of the structure has not changed significantly (displacement and accelera-

Table 2. Summary of results for building allowed to uplift and slide submitted to El Centro earthquake $\xi=0,05$

\begin{tabular}{|c|c|c|c|c|c|}
\hline $\begin{array}{c}\text { Cases } \\
\text { considered }\end{array}$ & $\begin{array}{c}\text { Shear wave } \\
\text { velocity } \\
\text { Vs (m/s) }\end{array}$ & $\begin{array}{c}\text { Max lateral } \\
\text { displacement at top of } \\
\text { Bldg }(\mathrm{cm})\end{array}$ & $\begin{array}{c}\text { Max axial } \\
\text { force } \\
(\mathrm{KN})\end{array}$ & $\begin{array}{c}\text { Max base } \\
\text { shear } \\
(\mathrm{KN})\end{array}$ & $\begin{array}{c}\text { Max base } \\
\text { moment } \\
(\mathrm{KN} . \mathrm{m})\end{array}$ \\
\hline Model A* & Encastré & 11,1 & 575,5 & 440,8 & 108,3 \\
\hline \multirow{2}{*}{ Model B* } & 50 & 16,9 & 617,6 & 327,0 & 0,0 \\
\cline { 2 - 6 } & 400 & 9,6 & 575,8 & 114,5 & 106,9 \\
\cline { 2 - 6 } & 1200 & 10,0 & 575,0 & 431,2 & 103,4 \\
\hline
\end{tabular}

* Model A: structure fully fixed at base, ie without SSI

* Model B: Non-linear SSI, taking into account possible uplift and slide of foundation.

Table 3. Summary of results for building allowed to uplift and slide (in terms of percent difference) submitted to El Centro earthquake $\xi=0,05$

\begin{tabular}{|c|c|c|c|c|c|}
\hline \multirow[b]{2}{*}{$\begin{array}{c}\text { Cases } \\
\text { considered }\end{array}$} & \multirow[b]{2}{*}{$\begin{array}{c}\text { Shear wave } \\
\text { velocity } \\
\text { vs, m/s }\end{array}$} & \multicolumn{4}{|c|}{ Percent difference $\%$} \\
\hline & & $\begin{array}{c}\text { Max lateral } \\
\text { displacement at top of } \\
\text { Bldg }\end{array}$ & $\begin{array}{l}\text { Max axial } \\
\text { force }\end{array}$ & $\begin{array}{c}\text { Max base } \\
\text { shear }\end{array}$ & $\begin{array}{c}\text { Max base } \\
\text { moment }\end{array}$ \\
\hline \multirow{3}{*}{$\begin{array}{l}\text { Model A \& } \\
\text { Model B }\end{array}$} & 50 & +43 & $+6,8$ & $-25,8$ & $-99,9$ \\
\hline & 400 & +1 & 0 & $-74,0$ & $-1,2$ \\
\hline & 1200 & 0 & 0 & $-2,2$ & $-4,4$ \\
\hline
\end{tabular}



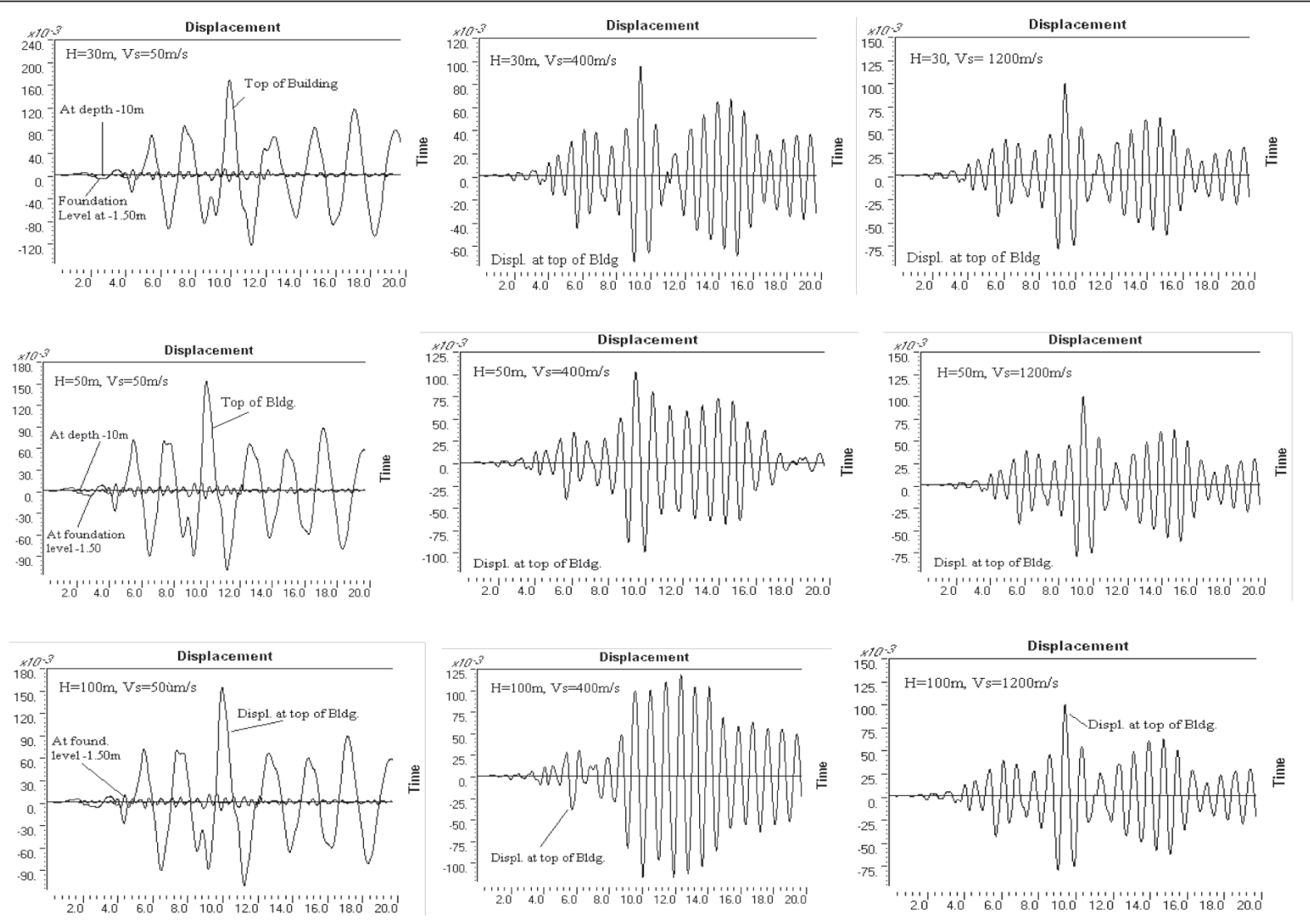

Fig 4. Displacement time history plots for $H=30,50,100 \mathrm{~m} ; V_{S}=50,400,1200 \mathrm{~m} / \mathrm{s}$

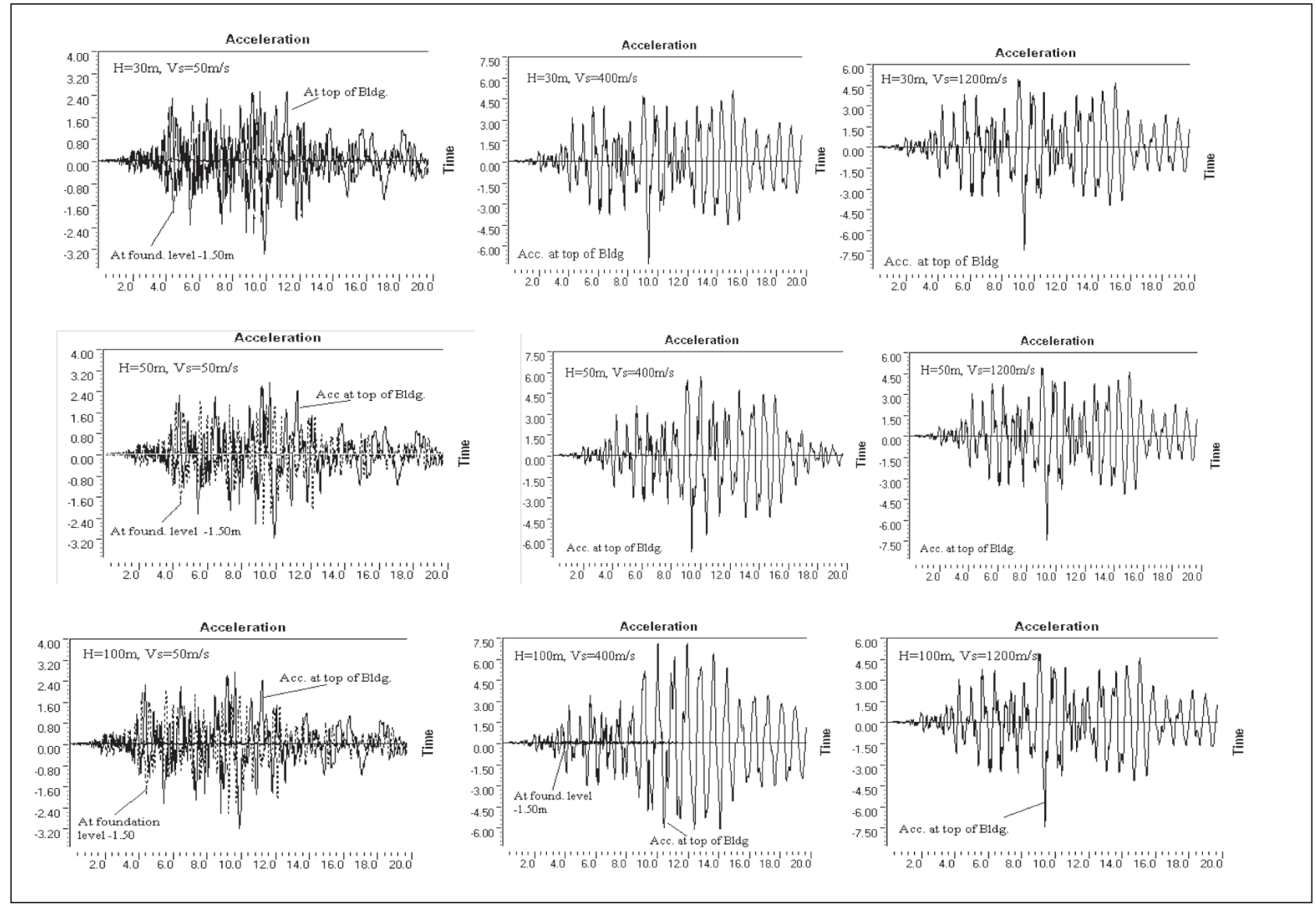

Fig 5. Acceleration time history plots for $H=30,50,100 \mathrm{~m} ; V_{S}=50,400,1200 \mathrm{~m} / \mathrm{s}$ 
tion time histories are given in Figs. 4, 5 respectively). However, allowing foundation uplifting reduces significantly the base shear $(-74,0 \%)$ and overturning moments (Table 3$)$.

In addition to the insight gained from SSI analysis, it improves our understanding of the behaviour of real structures. As a result, design and construction practices can be modified so that future earthquake damage is minimised. As reported in the literature, SSI analysis is seldom performed for ordinary structures. Even when SSI effects are negligible in terms of loads, they do affect structural stability in terms of large deflection and non linear response; this is rarely investigated.

It is possible to investigate such effects by first creating a model that represents the real structure and then perform a sensitivity analysis as for different support conditions allowing for the structure to uplift and slide.

\section{References}

1. The Boumerdes, Algeria, Earthquake of May 21, 2003. EERI Learning from Earthquakes Reconnaissance Report October 2003, Earthquake Engineering Research Institute, 2003-04.

2. JENNIGS, P. C.; BIELAK, J. Dynamics of building-soil interaction. Bulletin of the Seismological Society of America, 1973, 63, p. 9-48.

3. WOLF, J. P. Dynamic soil-structure interaction. Prentice Hall, 1985.
4. GAZETAS, G. Analysis of machine foundation vibrations: State of the Art. Journal of Soil Dynamics and Earthquake Engineering, 1983, 2, p. 2-42.

5. APSEL, R. J.; LUCO, E. Impedance functions for foundations embedded in a layered medium: an integral equation approach. Earthquake Engineering and Structural Dynamics, 1987, 15, p. 213-231.

6. BABA, K.; PARK, K.; OGAVA, N. Soil-Structure interaction systems on the base of the ground impedance functions formed into a chain of impulses along the time axis. In Proc of the Eleventh World Conference on Earthquake Engineering, Acapulco, Mexico, 1996.

7. WOLF, J. P.; SONG, C. Finite element modelling of unbounded media. West Sussex: John Wiley \& Sons, 1996.

8. MENGLIN, L.; JINGNING, W. Effects of soil-structure interaction on structural vibration control. In Dynamic SoilStructure Interaction: Current Research in China and Switzerland, eds Z. Chuhan \& J.P. Wolf, Elsevier Science, Amsterdam, 1998, p. 189-202.

9. BRINKGREVE, R. B. J., et al. Plaxis finite element code for soil and rock analyses. Delft University of Technology, The Netherlands, 1998

10. LYSMER, J.; KUHLMEYER, R. L. Finite dynamic model for infinite media. ASCE Journal of the Engineering Mechanics Division, 1969, p. 859-877.

11. ROSSET, J. M.; KAUSSEL, E. Dynamic soil-structure interaction. In Proc of the Second International Conference on Numerical Methods in Geomechanics, Blacksburg, Virginia, 1976, Vol 2, p. 3-19.

\section{NELINIJINĖ DINAMINĖ GRUNTO, SLŪGSANČIO PO PASTATAIS, STRUKTŪROS POKYČIŲ ANALIZE்}

\section{A. Gouasmia, K. Djeghaba}

\section{Santrauka}

Šio darbo tikslas - ịvertinti grunto struktūros pokyčiu įtaką esamiems statiniams. Dėmesys sutelktas i̇ procesus, kurie vyksta penkiaaukščiu gelžbetoninių pastatų, dažnai statomų Alžyre, konstrukcijose. Atlikti jautrumo tyrimai, siekiant nustatyti, kaip grunto virpesių dažnis, standumas ir sluoksnio gylis veikia minètu statinių konstrukcijas. Tyrimas atskleidè, kad grunto sluoksnio standumas yra svarbiausias veiksnys, sukeliantis grunto struktūros pokyčius ir galintis padidinti deformacijas gelžbetoninių pastatų konstrukcijose. Kita vertus, dideli po pamatais slūgsančio grunto poslinkiai sukels šoninius pastato poslinkius, dèl to persiskirstys šlyties sukelti įtempiai. Galimas drebëjimų judesių ir grunto savujjų svyravimų dažnių rezonansas taip pat gali sukelti didesnį poveikị konstrukcijoms.

Reikšminiai žodžiai: pamatai, gelžbetoninis rẻmas, grunto struktūros pokyčiai, standumas, tiesioginis metodas, baigtinių elementu metodas

Abdelhacine GOUASMIA. Master, Assistant Teacher. Dept of Civil Engineering, University of Badji Mokhtar, Annaba, Algeria. Engineer of civil engineering (1984). Master of Applied Science (1987).

Research interests: soil-structure interaction, earthquake resistant design, neural network methods.

Kamel DJEGHABA. Doctor, Associate Professor. Dept of Civil Engineering, University of Badji Mokhtar, Annaba, Algeria. Civil engineer (1984). Doctor (1990).

Research interests: structural analysis of structures, numerical methods, finite element method. 